\title{
The World History of Science Online: A Project of the Commission on Bibliography and Documentation
}

\author{
Stephen P. Weldon \\ Isis Current Bibliography of the History of Science \\ University of Oklahoma \\ 401 West Brooks Street, Room 521, \\ Norman, OK 73019-0528, USA \\ E-mail: spweldon@ou.edu
}

In the past ten years, the digital world has been transformed in several distinct ways. There is an enormous amount of information digitized, indexed, and available online. In addition, the development of social networking tools have transformed the way many scholars work. All of this change brings new possibilities but also many unfulfilled promises.

Despite the rise of such massive online tools as Google Books, JSTOR, and similar full-text databases, many needs have not been met. Only some of those tools are open to all, and many of the most useful have very high subscription costs. Furthermore, many of these resources are non-specific and do not meet the needs of historians' precise research methodologies. Even more challenging online resources of a scholarly nature are increasing very rapidly: websites, blogs, digital exhibits, lecture videos, bibliographical sharing tools, and other forms (Weller, 2011 ${ }^{1}$; see also drinehart, 2012).

The burgeoning of these online resources has prompted the World History of Science Online (WHSO) to create a database that will allow researchers to better find digital resources. WHSO is a project of the Commission on Bibliography and Documentation of the IUHPST/DHST, ${ }^{2}$ whose mandate is to encourage bibliographical and documentation efforts worldwide in the field of history of science (Railiene, 2013). WHSO, with its international board of advisors, was developed to integrate and develop international online resources. Although the

\footnotetext{
This is an extremely useful book in surveying the current environment for scholarship.

International Union for the History and Philosophy of Science and Technology/Division of History of Science and Technology (WHSO, 2012).
} 
WHSO project has indexed only a relatively small number of resources, there are plans over the next couple of years to significantly expand its reach. If this happens then it will help provide a solution to the current difficulties researchers have when they do web-based research. The WHSO is also regarded as a platform for archiving the abstracts of the IUHPST/DHST quaternary congresses.

\section{The history of WHSO}

The World History of Science Online turns ten years old in 2013, having been established at an expert meeting in Paris in 2003 at the Maison de Sciences de l'Homme. The founding meeting was convened by two prominent historians of science, Luca Scarantino and Juan José Saldaña, and was composed of about a dozen librarians, archivists, and scholars from several nations (WHSO, 2005).

The project had strong international institutional support. At that time, Scarantino was the assistant secretary of the Conseil International de la Philosophie et des Sciences Humaines (CIPSH) and Saldaña was Secretary General of the IUHPS/ DHST. Both DHST and CIPSH are historically connected to the International Council for Science (ICSU, n.d.), and this group has tended to see the discipline of history of science as the historical conscience of the scientific community (DHST, n.d., b). WHSO received strong initial support by ICSU for this reason (Aymard, 2004; Kazancigil, 2004).

At its outset, WHSO adopted a federated approach to bibliographical resources, one that emphasized the contributions of individual countries and that encouraged the creation of national bibliographies that promoted each country's own scientific heritage (WHSO, 2003; 2005).

At the 2005 Beijing meeting of the DHS (not yet DHST), Saldaña and archivist Peter Harper, director of the National Cataloguing Unit for the Archives of Contemporary Scientists at the University of Bath, held a symposium to discuss the development of WHSO. There were thirteen papers dealing with the problems of bibliography and archives (IUHPS, 2005, pp. 209-216).

The author of this overview participated in the 2005 Beijing meeting as editor of the History of Science Society's Isis Bibliography. He took over leadership of WHSO in 2006 in large part because WHSO offered him the opportunity to push for more open access of scholarly resources like the Isis Bibliography. 
Gavan McCarthy, who is the current director of the eScholarship Research Centre at the University of Melbourne, had been part of the WHSO project since its inception and agreed to take charge of the website and database at that time. When the WHSO website was migrated to the eScholarship Research Centre (in 2012), it was hosted on a platform specifically designed for digitallybased historical archive management (eSRC, n.d.).

WHSO has now developed into a website that contains a search engine for specialized online resources in history of science. One can find several hundred resources that have been located and categorized. It is meant to supplement the print resources classified in traditional bibliographical projects like the Isis Current Bibliography.

\section{How WHSO can facilitate research in the new digital research environment}

One of the problems of the new digital research environment is that there is a glut of information that makes it hard to narrow down the results to find the specific materials one needs. The world's literature may eventually all be indexed by Google Books (cf. Giangrande, 2012), but that is not enough for the historian of science. Specialized discovery tools continue to be essential. Scholars need precision tools; they need a discipline-based resource.

The mandate of WHSO is to find, document, and (where necessary and possible) preserve those digital resources. The variety of digital documents is extraordinary. They can include video and audio lectures, blogs, websites, and exhibits. Many of these are of very high quality and ought to become part of the long-term digital record of secondary source material for our discipline.

WHSO also seeks to document the gaps in the digital records of the past. In addition to the problem of an information glut in some areas, there is actually a deficit of information in others (DHST, n.d., a). Access to archival material is a particularly good example of this. Libraries all over the world have archives containing manuscripts, correspondence, and so-called gray literature ${ }^{3}$ that has never been digitized and may never be. The costs of digitization have meant that

\footnotetext{
3 Gray literature is informally produced literature such as reports, white papers, patents, and other such materials that have never been published in larger numbers. It is often for a small enough and specialized audience, but these materials are often of great use to the historian.
} 
only Newton and Darwin and a few others can be properly processed. Only the best-known scientists pass through because of the cost and lack of expertise. Even digitizing finding aids challenges many institutions, and this is where WHSO can help by encouraging institutions to push forward with their digitization efforts, even minimal ones, making records of primary source material and their scope and content.

Finally, WHSO is aware of the importance of the social network to scholarship. The Internet has brought people together in obvious places, in areas such as LinkedIn and Facebook and Twitter; and scholars have found ways to use all of these generic tools for their own work. These tools can be important in developing specialized networks of collaborators and discussion groups. Sub-communities can be sustained with these tools. Most immediately, WHSO is looking at ways in which scholars share bibliographical information via social tools like Diigo, Mendeley, and Zotero.

In coming year, the author will be working on ways to merge the WHSO database with an online open-access version of the Isis Bibliography. This platform will allow researchers to search both online and print resources, and it will not only have a sophisticated discovery tool at its core, it will also be much more directly linked to online resources and tools that take advantage of the social networking possibilities of the web.

From its origins only ten years ago, WHSO has moved quite far. It now works as both an online resource as well as an advocacy organization for the organization and preservation of resources internationally for the history of science and technology.

\section{References}

Aymard, M. (2004), M. Aymard's letter to J. J. Saldańa, communication from 29 November 2004. Retrieved from http://www.dhst-whso.org/objects/docs/ cartaweb1.pdf [accessed 27 Jan 2013]

eSRC (n.d.), About the eScholarship Research Centre (eSRC), The University of Melbourne.

Retrieved from http://www.esrc.unimelb.edu.au/about/about.html [accessed 27 Jan 2013]

DHST (n.d., a), '40 IUHPS Outline Dictionary of National History of Science Bibliographies and Archival Sources (Funding Continuation).' Retrieved from 
http://www.dhst-whso.org/objects/docs/3.1.4\%20Second\%20ICSU\%20approval. pdf [accessed 27 Jan 2013]

_ _ (n.d., b), "The Members' Vademecum: A Short Historical Note on the DHST.” Retrieved from https://sites.google.com/a/dhstweb.org/www/ themembers\%27vademecum [accessed 27 Jan 2013]

drinehart (2012), '10,000,000,000,000,000 bytes archived!' [blog] Internet Archive Blogs, 26 October, 2012.] Retrieved from http://blog.archive. org/2012/10/26/10000000000000000-bytes-archived [accessed 27 Jan 2013]

Giangrande, M. (2012), 'Google Book Scan Project Slows Down,' Law Librarian Blog: A Member of the Law Professor Blogs, 12 March 2012. Retrieved from http:// lawprofessors.typepad.com/law_librarian_blog/2012/03/google-book-scan-projectslows-down.html [accessed 27 Jan 2013]

ICSU (n.d.), A Brief History of ICSU. Retrieved from http://www.icsu.org/about-icsu/ about-us/a-brief-history [accessed 27 Jan 2013]

IUHPS (2005), Book of Abstracts, 'Globalization and Diversity' XXII International Congress of the History of Science, 24-30 July, Beijing, International Union of History and Philosophy of Science. Retrieved from http://2005bj.ihns.ac.cn/pdf/ ICHSAbstracts.pdf [accessed 27 Jan 2013]

Kazancigil, A. (2004), Letter to J. J. Saldaña, 1 December 2004. Retrieved from http:// www.dhst-whso.org/objects/docs/issc.pdf [accessed 27 Jan 2013]

Railienè, B. (2013), 'Bibliographic Control for History of Science: Commission on Bibliography and Documentation of the IUHPST/DHST,' Acta Baltica Historiae et Philosophiae Scientiarum, vol. 1, no. 2, pp. 91-96.

http://dx.doi.org/10.11590/abhps.2013.2.08

Weller, M. (2011), The Digital Scholar: How Technology Is Transforming Scholarly Practice, London \& New York: Bloomsbury Academic.

WHSO (2003), "Paris Minutes: Minutes of the Expert Committee Meeting for the 'Online Dictionary of National History of Sciences Bibliographies and Archival Sources', 4-6 April 2003. Venue: Maison de Sciences de l'Homme, Paris, France”. Retrieved from http://www.dhst-whso.org/about/history-of-whso/paris-minutes [accessed 27 Jan 2013]

(2005), "Project Outline: The 'World History of Science Online: Databases of Bibliographical and Archival Sources' project.” Retrieved from http://www.dhstwhso.org/about/history-of-whso/project-outline [accessed 27 Jan 2013]

(2012), World History of Science Online [homepage]. Retrieved from http://www. dhst-whso.org [accessed 27 Jan 2013] 